\title{
LUNGESYKE TRENGER PLANLAGTE STELL
}

\section{Blir ofte et strev. Sykepleier bør ta seg god tid til stell og la} pasienten få pauser for å unngå anfall av tungpustethet.
FAGARTIKKEL:

Artikkelen bygger på $20 \%$ pralksis $80 \%$ teori

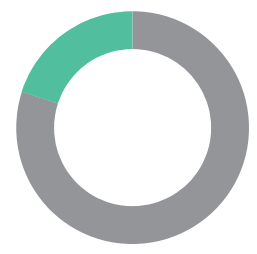

DOI-NUMMER:

10.4220/Sykepleiens.2016.56193



Trine Oksholm, sykepleier og PhD student, Haraldsplass diakonale høyskole og Lungeavdelingen, Rikshospitalet, OUS



Henny Torheim, intensivsykepleier og høyskolelektor, Høgskolen i Ålesund

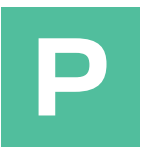

asienter med alvorlig lungesykdom er ofte tungpustet både under aktivitet og hvile (1). De opplever det å bli tungpustet som svært slitsomt og planlegger ofte dagen slik at de unngår dette (2). Resultatet er at de utsetter aktiviteter som kroppspleie, hårvask og dusj, selv om de egentlig kunne tenke seg dette, fordi de føler at de ikke orker (3).

Lungesyke pasienter trenger mye hjelp for å utføre daglige rutiner som kroppsvask. Å skulle hjelpe lungesyke pasienter med stell kan være en utfordring for sykepleiere. På den ene siden ønsker sykepleier at pasienten skal få den hjelpen han har behov for. På den andre side vil man gjerne at han skal gjøre det han klarer selv, for å stimulere ham til aktivitet.

Vi er to sykepleiere med lang erfaring som har arbeidet mye med lungesyke pasienter. Vi har møtt flere pasienter som forteller om dårlige opplevelser med å få hjelp til stell. En pasient valgte heller å bruke to timer på å stelle seg selv fremfor å få hjelp. Begrunnelsen var at sykepleierne alltid hadde det så travelt, noe som førte til anfall med tungpustethet som ødela hele dagen hennes. Pasienten var underernært og i dårlig form og burde kanskje heller brukt kreftene på å spise og trene og ikke på å stelle seg i timevis.
HAR DET TRAVELT. Et argument sykepleieren ofte bruker for å forsvare måten de utfører stellet på er at de har det travelt. Imidlertid har vi erfart at dårlig planlagte stell, der pasienten gjerne får flere anfall med tungpustethet, ofte tar mye lengre tid enn godt planlagte stell.

En måte å måle pasientens subjektive opplevelse av tungpustethet på er å bruke Borg CR10-skala. Den er konstruert for å måle en persons subjektive opplevelse av noe, for eksempel dyspne (4). Det er en skala fra 1-10, hvor 1 er ingen tungpustethet og 10 er ekstremt tung pust. Denne brukes underveis i stellet for å måle pasientens tungpustethet.

HVA SOM SKJER VED STELL. Forskning om hvordan pasienter opplever å leve med kronisk obstruktiv lungesykdom (kols) viser at hverdagen ofte er preget av pusteproblemer, angst, utmatting og isolasjon (5-7), særlig i siste del av livet $(8,9)$.

Om selve stellet finnes det få studier. Vi har bare funnet tre artikler fra en dansk studie utført av Kirsten Lomborg på temaet $(3,10,11)$. I studien observerte hun stell av tolv pasienter med diagnosen kols innlagt på sykehus. Etterpå hadde hun intervju med sykepleier om hva som hadde skjedd i stellet. To timer etter stellet gjorde hun intervju med pasienten. I intervjuet ble de spurt om egen erfaring med å leve med kols, erfaring med å motta pleie og omsorg fra helsepersonell og stellesituasjonen som var observert. Til slutt ble det utført et dybdeintervju med de fire sykepleierne som deltok i studien, der man vektla deres forståelse av pleie og omsorg og om kolspasienter generelt.

Funnene fra studien stemmer mye overens med det vi selv har erfart ved stell av alvorlig lungesyke. I denne artikkelen blir først resultatene fra studien presentert. Deretter blir de drøftet ut fra praktisk erfaring og relevant litteratur. Hensikten med denne artikkelen er å gi ideer til hvordan stellet kan gjøres på en god måte.

PASIENTENS OPPLEVELSE. PaSientene i Lomborgs studie $(3,10,11)$ syntes det var svært viktig å få stelt seg jevnlig, men ønsket at det ble gjort på en måte som bevarte deres integritet. De var redde for å bli tungpustet under stellet fordi de tidligere hadde hatt skremmende opplevelser av å miste kontrollen. Enkelte pasienter observerte oksygenslangen kontinuerlig. Pasienten satte pris på forutsigbarhet under stellet, for eksempel ved at sykepleier ga beskjed om hva som skulle skje i god tid.

Pasientene var bekymret for sin
Fakta

Hoved-

budskap

Deter viktig at sykepleier fokuserer på pasientens opplevelse av tung pust når de hjelper alvorlig lungesyke pasienter $\mathrm{i}$ stellsituasjoner. Sykepleierne må forsikre pasienten om at de forstår deres behov for åfåhjelp underveis istellet. En felles forståelse av pasientens tilstand vil gjøre stellet lettere for både pasient og sykepleier. Det er viktig å unngå unødvendige elementer, som pasientundervisning og mobilisering, underveisistellet.

Nokkelord

Les mer og finn litteraturhenvisninger på våre nettsider

- Lungesykdom

- Kronisk sykdom

- Undervisning

- Mestring 


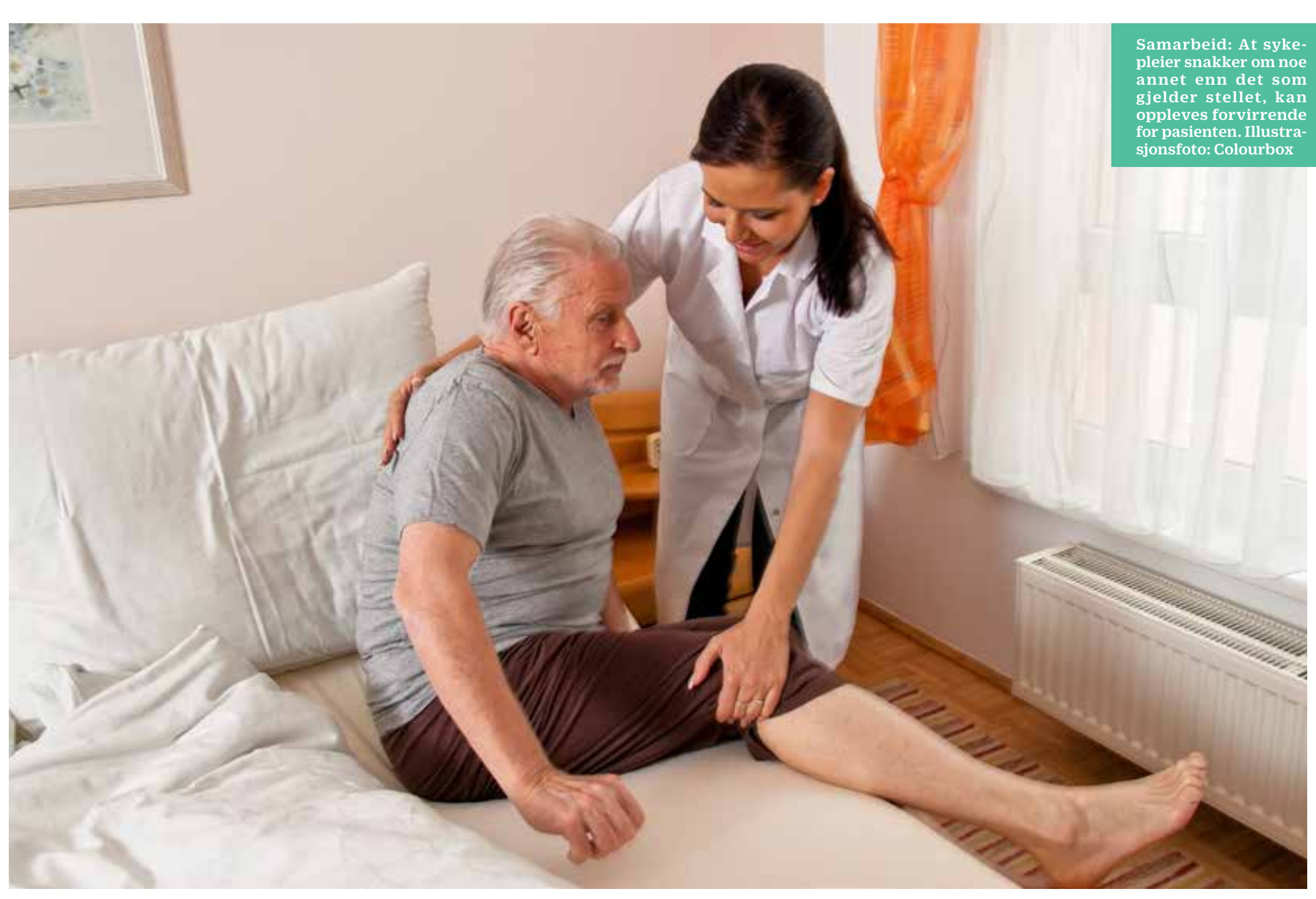

«skjulte sykdom» og redde for at sykepleieren undervurderte alvorlighetsgraden av sykdommen. De bekymret seg for om de var en "god pasient", noe som gjorde at de legitimerte sitt behov for hjelp ved stadig å demonstrere hvor tungpustet de var. Ønsket om å være en «god pasient» kolliderte med ønsket om å spare på kreftene. Det første ble prioritert og pasientene tok derfor ikke pauser i stellet eller brukte den tiden de trengte. Ingen sykepleiere spurte pasienten direkte om deres opplevelse av tung pust. Pasienten opplevde sykepleierne som travle og mente at travelheten hindret en felles beslutning.

Pasientene i studien foretrakk egentlig å dusje, men ønsket stell i seng under innleggelsen fordi det var mindre anstrengende. Stellet ble oppfattet både positivt og negativt. Det var positivt å bli berørt, massert og å være sammen med sykepleieren. Det negative var at det var slitsomt, ubehagelig, at de ble tungpustet og at de følte seg sårbare fordi de ikke klarte å stelle seg selv.

Pasienten satte pris på at sykepleieren var serviceinnstilt og gjorde enkle ting som litt massasje,

\section{«Pasientene følte ofte at de måtte mase om hjelp.»}

ristet puten eller dekket til pasienten slik at de ikke ble kalde. Dette ble satt pris på både av praktiske årsaker og som et bevis på sykepleierens omsorg. Når sykepleieren tilbød hjelp, så viste de at de så på pasientene som verdifulle mennesker, men pasientene følte ofte at de måtte mase om hjelp.
SYKEPLEIERS UTFORDRING.

Lomborgs studie $(3,10,11)$ viser at når sykepleier skal hjelpe en pasient med kroppspleie, avhenger pasientens opplevelse mye av sykepleierens mellommenneskelige kompetanse og kommunikasjonsevne. Selv om sykepleierne mente at pasientens kroppspleie var viktig, hadde de problemer med å prioritere dette på en travel avdeling. Studien viste at kun i ett av de tolv stellene hadde sykepleieren hatt ansvaret for pasienten dagen før. Dette vanskeliggjorde stellet. 
Hvordan stellet påvirket pasientens dyspné varierte. Noen fikk økt dyspné på grunn av aktivitet eller stress. Andre merket reduksjon av dyspné, blant annet når sykepleier var rolig.

Sykepleierne hadde en tendens til å undervurdere hvor tungpustet pasienten var. Når sykepleier ble bedt om å vurdere hvor tungpustet pasienten var før og etter stellet, oppga hun eller han lavere verdi på BORG-skala enn pasienten i syv av tolv tilfeller. I de øvrige fem tilfellene var pasienten og sykepleierens vurdering den samme.

Da forsker observerte stellet av pasienten, viste det seg at det var to hovedmønstre av stell. I den ene typen stell var de ulike delene av stellet klart atskilt. I den andre typen stell ble også andre aktiviteter gjort parallelt. I dette tilfellet brukte sykepleier tiden under stellet til også å undervise, mobilisere og oppmuntre pasienten. Av og til stilte de pasienten spørsmål når de tydelig var opptatt med andre ting, som å pusse tenner. Noen pasienter svarte høflig, mens andre ignorerte spørsmålene. Forsker stilte spørsmål ved om det er riktig å blande så mange aktiviteter inn i stellet.

Sykepleierne satte ikke opp mål for stellet på forhånd, men ventet for å se hva som skjedde. Dette begrunnet de med at tidligere erfaring tilsa at tilstanden for pasienter med kols var uforutsigbar. Sykepleierne i studien uttrykte at selv om de visste hvordan et godt stell skulle gjennomføres, så fikk de av ulike grunner ikke alltid det til. Det ble ikke gjort noen felles evaluering etter noen av stellene.

PASIENT - SYKEPLEIE-INTERAKSJON. Studien viste at både pasient og sykepleier anstrengte seg for å gjennomføre stellet på en slik måte at pasientens behov ble møtt $(3,10,11)$. Begge så verdien av et rolig, forutsigbart og effektivt stell og var opptatt av å bli enige om hva som skulle gjøres. Slik enighet forutsatte en felles forståelse av pasientens sykdomstilstand, klargjorte roller og felles mål for stellet. Selv om forsøk på å oppnå enighet ble gjort, viste studien at pasient og sykepleier ofte hadde ulike forventninger og mål under stellet.

Ulikheten var opphav til tre hovedproblemer:

- Manglende forståelse for pasientens nåværende pleiebehov gjorde at sykepleieren ble nølende.

- Sykepleierens forsøk på å fremme pasientens egenaktivitet feilet, fordi målet med stellet ofte var uklart og at stellet hadde en rotete struktur.

- Uklare rolleforventninger vanskeliggjorde pasientens mestring av det å være avhengig av andres hjelp og av å være tungpustet.

SYKEPLEIER VILLE DISKUTERE. I stellet var pasienten oppgaveorientert, mens sykepleier var opptatt av det psykososiale aspektet og fremming av pasientens egenomsorg på lang sikt. Et slikt framtidsrettet initiativ fra sykepleier førte ofte til vanskeligheter. Under stellet tok sykepleier initiativ til en diskusjon om hvordan pasienten ville klare seg hjemme etter utskriving. Etterpå vurderte sykepleier dette som en konstruktiv samtale med pasienten. Pasienten var derimot helt uforstående til hva sykepleieren mente med å ta opp et slikt spørsmål og husket ikke helt hva de hadde snakket om i ettertid.

\section{PASIENTEN TOK IKKE INITIA-} TIV. Alle pasientene hadde en formening om hva de ville skulle skje under stellet, men tok initiativ kun i to av tolv tilfeller. Det vanlige mønstret var en passiv pasient og en dominerende sykepleier. Det virker som om sykepleieren var ukomfortabel med dette, og hun inviterte stadig pasienten til å være med og ta bestemmelser. Pasienten så på en aktiv rolle som slitsom og ubehagelig, og opplevde det som negativt og stadig måtte be om hjelp. De foretrakk at sykepleier overtok på eget initiativ, men opplevde at sykepleieren overså en rekke av deres behov. Dette førte til at pasienten stadig måtte be om hjelp.

Uklar ansvarsfordeling mellom pasient og sykepleier gjorde at det av og til oppsto en maktkamp. I diskusjonene som oppsto virket det som om pasienten opplevde sykepleieren som stresset og lite villig til å hjelpe. Sykepleieren tolket pasientens innstilling som motvilje og oppfattet dem som ganske krevende.

TRENGTE PAUSER. Fordi pasienten var tungpustet var det viktig med pauser under stellet. Det var ofte uklart hvem som skulle ta initiativ til pausene, hvor lenge de skulle vare og hvem som skulle avslutte dem. Mangelen på

\section{pauser kan ha flere}

«Sykepleiere har en tendens til å undervurdere hvor tungpustet pasientene er.» årsaker: 1. En travel atmosfære i avdelingen gjorde det vanskelig. 2. Sosiale regler kunne få sykepleieren til å begrense dette fordi det ikke er vanlig å være til stede uten å tilby hjelp. 3. Pasienten klarte ikke å vurdere sin egen dyspné og ga derfor ikke uttrykk for når han eller hun trengte pauser og hvor lenge. Pausene underveis i stellet ble ofte avbrutt av snakking, enten av pasient eller sykepleier. Dette gjorde at pasienten ikke fikk anledning til å «få igjen pusten».

TIL DISKUSJON. Hvordan gjennomføre et godt stell av lungesyke?

Lomborgs studie har gitt ny innsikt og forståelse av hvordan lungesyke pasienter opplever å bli stelt. Når pasienten er alvorlig syk, er deres evne til å vurdere og diskutere seg fram til hva som skal gjøres begrenset. Sykepleier er derfor ansvarlig for å finne ut hvor mye pasienten klarer og på hvilken måte de skal delta i stellet. En felles forståelse av pasientens tilstand vil gjøre stellet lettere for begge, mens manglende forståelse ofte fører til at sykepleier blir nølende. Hjelp til kroppspleie fører til nær fysisk kontakt mellom pasient og sykepleier, noe som kan være starten på et nært og omsorgsfullt pasient - sykepleier forhold.

Fordi tung pust er et svært sen-
FAGARTIKLER:

Fagartikler kan sendes til torhild.apall@ sykepleien.no tralt problem for lungepasienter, må sykepleieren veie dette opp mot aktivitetene som må utføres. Stellet bør gjøres på en måte som 
hjelper pasienten til å beholde sin integritet, samtidig som det fremmer egenaktivitet og velvære.

Flere studier påpeker at pasienter med alvorlig kols er i en sårbar situasjon der de er avhengig av andre. Hvordan de blir møtt og opplever hjelp vil derfor påvirke deres livskvalitet, mestringsevne og sosiale forhold (3,10-13). Å møte pasientens sårbarhet og avhengighet med omsorg krever at sykepleier er sanselig til stede i situasjonen og bruker faglig skjønn (14-16). Ofte trenger pasienter hjelp til deler av stellet, som for eksempel hårvask, selv om de klarer resten av stellet selv. Pasienten blir ofte veldig takknemlig for å få tilbud om hjelp til dette, slik at de slipper å be om det. En pasient beskrev det på følgende måte: «Jeg skulle ønske jeg ble tilbudt hjelp istedenfor at jeg må be om hjelp. For da fikk jeg tid istedenfor at jeg måtte ta av andres travle tid" (17).

Før oppstart bør man sette opp mål for stellet. Studier viser at pasienter med kols er eksperter på egen kropp relatert til sykdommen, og at de har utviklet egne mestringsstrategier for å regulere tung pust $(18,19)$. Tidspunkt for stell er også viktig å bli enige om. Lungesyke er ofte mest tungpustet om morgenen og trenger ofte å hvile etter stellet (20). En stund etter frokost er ofte et bra tidspunkt. Da har pasienten spist mat, tatt morgenmedisiner og er ikke for sliten. Det er viktig at sykepleier har kunnskaper om behov for ekstra medisinering før stellet, og ekstra oksygentilførsel under stellsituasjonen for å unngå fall i oksygenmetning.

God tid og ekspertise er viktig for at stellet skal bli bra (21). Slik ekspertise utvikler man ved å gjennomføre stell og snakke med pasienten om deres opplevelser. Et godt stell krever god timing med begrenset bruk av informasjon og instruksjoner. Pasientene opplever både travelhet og nøling som slitsomt og det bør derfor unngås. Det er viktig å lytte til kroppens rytme og tilpasse farten på stellet til den (17). Pasientens sengeleie har stor betydning for lungekapasiteten under stellet, ofte foretrekkes høyt toraksleie. Pasienten kan oppleve økt tungpustethet når de ligger på siden. Vår kliniske erfaring er at mange pasienter foretrekker å stelle seg på sengekanten fremfor å bli snudd fra side til side. Hvilken stilling pasienten ønsker bør diskuteres før stellet starter.

Sykepleier bør spørre pasienten underveis i stellet om hvor tungpustet de er, slik at sykepleier og pasient får en felles forståelse av pasientens tunge pust og når han eller hun trenger pauser. Man kan bruke BORG-skala for å vurdere endring og alvorlighetsgrad av tungpustethet.

Flere studier viser at sykepleiere har en tendens til å undervurdere hvor tungpustet pasientene er $(3,22)$. Enkelte pasienter trenger flere, lange pauser for å klare å gjennomføre stellet. Sykepleier bør unngå for mange unødvendige elementer, som pasientundervisning og mobilisering underveis i stellet. Pasienten vil ofte ikke oppfatte dette og bli unødvendig sliten. Er pasientene svært dårlige er det å få nok luft det vesentlige (23).

Det er viktig at sykepleier er oppmerksom under stellet, slik at pasienten unngår å bli for tungpustet, samtidig som sykepleier forsikrer pasienten om at de forstår deres behov for å få hjelp. Etter stellet bør sykepleier og pasient sammen evaluere stellsituasjonen. Dette kan styrke pasientenes opplevelse av medvirkning og være viktig for sykepleierens læring (24).

OPPSUMMERING. Det kan være en god opplevelse for pasienter å få hjelp med stell, men Lomborgs studie viser at dette ikke nødvendigvis skjer. En positiv opplevelse av stellet forutsetter god planlegging og at det oppstår en felles forståelse mellom pasient og sykepleier. Pasientens integritet og velvære, samt å støtte opp under pasientens mestringsstrategier, må proriteres. Det viktigste under stellet er: 1. Planlegg stellet sammen. 2. Skap en omsorgsfull atmosfære. 3. Ta hensyn til pasientens tunge pust. 4. Økonomiser med pasientens energi. •

\section{REFERANSER:}

1. Gysels M, Bausewein C, Higginson IJ.Experiences of breathlessness: a systematic review of the qualitative literature. Palliat Support Care 2007; 5(3): 281-302.

2. Andenæs R, Kalfoss MH, Wahl AK. Coping and psychological distress in hospitalized patients with chronic obstructive pulmonary disease. Heart Lung 2006; 35(1):46-57.
3. Lomborg K, Bjørn A, Dahl R, Kirkevold M. Body care experienced by people hospitalized with severe respiratory disease. J $A d v$ Nurs 2005; 50(3), 262-271.

4. Borg G. Borgss perceived exertion and pain scales. Champaign ILUS: Human Kinetics, 1998.

5. Nicholls DA. The experience of breathlessness. Physiotherapy Theory and Practice 2003; 19: 123-136

6. Fraser DD, Kee CC, Minick P. Living with chronic obstructive pulmonary disease: insiders) perspectives. J Adv Nurs 2006 ;55(5):550-8

7. Barnett M. Chronic obstructive pulmonary disease: a phenomenological study of patients) experiences. J Clin Nurs 2005 ;14(7):805-12

8. Gysels M, Higginson IJ. Access to services for patients with chronic obstructive pulmonary disease: the invisibility of breathlessness.J Pain Symptom Manage2008;36(5):451-60.

9. EkK, Ternestedt BM. Living with chronic obstructive pulmonary disease at the end of life: a phenomenological study. J Adv Nurs 2008; 62(4):470-8.

10. Lomborg K, Kirkevold M. Curtailing: handling the complexity of body care in people hospitalized with severe COPD. Scand J Caring Sci 2005; 19: 148-156

11. Lomborg K, Kirkevold M. Achieving therapeutic clarity in assisted personal body care: professional challenges in interactions with severely ill COPD patients. Journal of clinical nursing 2008;17(16):2155-2163.

12. Nicolson P, Anderson P. Quality of life, distress and self-esteem: a focus group study of people with chronic bronchitis. $B r$ Health Psychol2003; 8(3): 251-70.

13. Williams V, Bruton A, Ellis-Hill C, McPherson K. What really matters to patients living with chronic obstructive pulmonary disease? An exploratory study.Chron Respir Dis2007;4(2):7785.

14. Martinsen K, Eriksson K. The hidden and forgotten evidence. Scand J Caring Sci 2012; 26(4): 625-626.

15. Martinsen K: Løgstrup og sykepleien (Løgstrup and Nursing). Oslo: Akribe AS, 2012 .

16. Martinsen K. Care and vulnerability. Oslo: Akribe as, 2006.

17. Ellingsen S, Roxberg $\AA$, Kristoffersen K, Rosland JH, Alsvåg H. "Entering a world with no future: A phenomenological study describing the embodied experience of time when living with severe incurable disease.) Scand J Caring Sci2013:27(1):165-174.

18. Kerr A, Ballinger C. Living with chronic lung disease: an occupational perspective.J Occup Sci 2010;17(1):34-9.
coliti

19. Gullick J, Stainton MC. Living with chronic obstructive pulmonary disease: developing conscious body management in a shrinking life-world.J Adv Nurs2008;64(6):605-14.

20. Roche R, Chavannes N, Miravitlles M. COPD symptoms in the morning: impact, evaluation and management. Respir Res 2013; 14(1):212-224.

21. Jeon YH, Essue B, Jan S, Wells R, Whitworth JA. Economic hardship associated with managing chronic illness: a qualitative inquiry.BMC Health Serv Res2009;9(1):182

22. Habraken JM, Pols J, Bindels PJE, Willems DL. The silence of patients with end-stage COPD: a qualitative study. $B r J$ Gen Pract2008;58(557):844-9.

23. Torheim H, Kvangarsnes M. How do patients with exacerbated chronic cobstructive pulmonary disease experiencecare in the intensivecareunit? Scand J Caing Scizol4 Dec:28(4):741-8. 24. Kvangarsnes M, Torheim H, Hole T, Ohlund LS. Intensive care 24. Kvangarsnes $\mathrm{M}$, Torheim $\mathrm{H}$, Hole T, Ohlund LS. Intensive care
unit nurses perseptions of patient participation in the acute phase of chronic obstructive pulmonary disease exacerbation: an interviewstudy. J Adv Nurs 2013;69(2):425-434

\section{6 - ÅRET DÅ DET HÄNDER!}

2016 blir ett intensivt år på Karolinska. Mycket av det som planerats inom ramen för Framtidens hälso-och sjukvård kommer att bli verklighet. Vi ska genomföra flytten till det nya toppmoderna sjukhuset i Solna samtidigt som ett nytt hus för operation och intervention byggs i Huddinge!

Vill du vara med på vår resa till ett centrum för högspecialiserad vård?

Gå in på www.karolinska.se/framtida-karolinska för mer information och lediga tjänster!

\section{KAROLINSKA}



